\title{
Creating videos to assist students' understanding of the graduate recruitment process
}

\author{
Noel-Ann Bradshaw \\ University of Greenwich
}

\begin{abstract}
This case study describes how a Greenwich Seed Fund project, using a kit comprising several video cameras, has helped to combat student apprehensions regarding many aspects of the graduate job application process.
\end{abstract}

\section{Introduction}

The use of video within HE teaching is well-known and well-documented. Advocates say that videos increase student motivation and aid the development of learner autonomy (Wilmot et al, 2012). The trend towards flipping the classroom in recent years has resulted in greater use of video and, consequently, it is a medium that students are familiar with.

There is evidence to suggest that there is a connection between memory retrieval and visual cues (Shepard and Cooper, 1982; Mayer and Gallini, 1990). For students who need to learn a new process or technique, video allows them to learn actively by pausing, rewinding and replaying parts of the recording (Galbraith, 2004), so that they can understand the material at their own pace. In cases where students are actively involved in creating the videos, this further helps the material to stick in their minds, as well as providing them with transferable skills such as research, team working, problem solving and technological and organisational skills (Hakkarainen, 2009).

Many universities have supplemented their careers provision with online videos that students, and indeed staff, can watch when they want to (Greenbank, 2012). This enables the advisory capacity of the careers service to be accessible twenty-four hours per day. Another example is from Leeds Metropolitan University, where staff have used video case studies of entrepreneurial role models within a curriculum-based module (Robertson, 2003).

Given that students of this generation have been brought up with instant answers through internet-available media such as YouTube and Facebook, it is no wonder that some companies are also using video to communicate with them. Shaw (2008) describes how MacDonald's uses videos in its staff development programmes to underpin the key aspects of its graduate training.

\section{Motivation}

Many students at the University of Greenwich are first generation participants in HE (Barnes, 2012). Parents and relatives of students from these backgrounds often have clerical rather than managerial positions and, as a result, the students to do not have the support and professional networks that graduates from other backgrounds take for granted (Roberts and Holton, 2015). 
Coupled with this is the fact that, within the topic of employability, students are apt to be passive rather than active learners. They like to be told what to do and how to behave, but do not always realise that they have not fully understood the significance of what has been said. For example, it is hard to describe a graduate job interview or a networking event in a way that enables these students to visualise it, understand how to prepare for it or appreciate the importance of a practice session in advance of it.

These students are also less able to articulate their concerns. Bradshaw et al (2015) describe organising mock interviews run for students by a recruitment company in the financial sector, when some students failed to attend because of their fears about what to expect. As a result, it was felt that showing students first-hand what an interview entails would help alleviate their worries and help them to realise why they needed to prepare.

\section{Project}

Greenwich Connect is the name given to the University of Greenwich's vision for learning innovation (University of Greenwich, 2014). Endorsed in 2013, the strategy is designed to recognise and promote a variety of technology-enhanced curriculum innovations. These support all aspects of learning and teaching, with an emphasis on social interaction (in and out of the classroom), digital literacy and collaborative learning. In order to help staff to experiment with some of these new technologies, a seed fund was set up to enable the borrowing of digital equipment that departments could not themselves afford to buy, for use in teaching and learning environments. Various kits are available, such as iPads, video cameras and podcasting equipment.

A successful application for a Greenwich Connect seed fund kit enabled several video cameras to be borrowed. However, though the initial idea was to ask students to create videos on employability topics that they considered interesting, very few of them suggested project ideas and lack of time militated against staff motivation strategies.

Fortunately, the Greenwich Graduate Work Experience Scheme (GWES) in 2015 made it possible for the project to take on a graduate intern with film experience to lead this work. She contacted several students, took up their ideas and trained them to take a role in the actual filming. She was also invited to some employability workshops, run by staff and graduates, which led to the creation of a number of short, stand-alone videos on topics such as CVs, extra-curricular activities, mentoring and placements.

These videos were augmented by others featuring staff demonstrations of good, and not so good, ways to answer competency-based interview questions and to deliver presentations. There were filmed by a member of the Greenwich Connect team. Some of these have been made available on YouTube, whereas others may be accessed only by students, via the University VLE.

\section{Student Feedback}

Several students were involved in the actual filming of the videos. They were from various disciplines, including architecture and film. The architecture students benefited from having something totally different to add to their CVs and the film students found the project useful for their intended careers. Comments include: 
"I am interested in camerawork but before the project, I did not have experience with filming interviews. I agreed thinking that it would be good opportunity for me to develop new skills and test working in a different domain. The project also attracted me because it was a professional environment."

"The project was a valuable experience as I faced new situations. For example I had to work at a fast pace and find good angles for the shots in various new locations, while interacting with the interviewees. Overall, it helped improve my skills and gave me more confidence."

Students who took part in the videos found the experience helpful as well; those who had come up with the initial ideas for the videos were particularly gratified to see their suggestions take shape on film. Comments from them include:

"I improved my communication skills, especially as I had never answered questions while being recorded, so it did make me a bit nervous. However, due to the experience gained from taking part in this short film, I am now happy to be involved in any future activities that are similar, so I can say that taking part in this project has also improved my confidence. Furthermore, I also gained the satisfaction of knowing that I tried to share my knowledge with others."

One student who agreed to be filmed about his placement has since gone on to write a guide on how best to obtain a place on a graduate scheme; his increased confidence has also enabled him to give a talk at the LSE on the reasons for studying mathematics and economics at university.

Students who have watched the videos have commented that they offer both enjoyable viewing and serious points and said that, as many of them previously had no idea about what a graduate job interview is like, they found the videos of interviews very helpful:

"Seeing a mock job-interview gave me an idea of what a real interview would be like."

The placements video has had the most views, seeming to have been motivational in generating student interest in applying for placements. Additionally, student take-up of other opportunities, such as a business simulation activity and mock assessment centres, has increased from last year.

\section{Further work}

Access to good video cameras would be essential to any replication of this project though Stoneham (2016) describes encouraging students to create videos with the use of Panopto (lecture-capture software). The use of these and similar technologies do provide students with the ability to create numerous short videos on various aspects of their learning.

As a result of this work, staff have seen the benefit to students of videos covering numerous aspects of employability. A company called Abintegro runs a career portal containing many activities and a vast quantity of useful videos, many of which feature employers and recent graduates talking about their roles and how they obtained them. This resource is now available for all students at the University of Greenwich under the name 'My Career Builder'. 


\section{Conclusion}

Using these videos to augment sessions on aspects of employability provision has helped students to understand that they need to practise skills relating to the stages of applying for and securing a job. This project experience also suggests that other departments and faculties might be interested in creating similar videos to help their students.

\section{Reference list}

Abintegro (2016) The Career Centre. Available at: http://www.abintegro.com/public/universities (Accessed: 26 February 2016).

Barnes, T. (2012) Enhancing Employment Outcomes at the University of Greenwich. London: The University of Greenwich.

Bradshaw, N., Mann, T. and Ramesh, N. (2015) Working with Employers. In: Proceedings of The CETL-MSOR Conference 2015. Sigma.

Greenbank, P. (2012) Resources on Employability. Edge Hill University Available at: https://www.edgehill.ac.uk/clt/files/2012/02/Resources-on-employability.pdf (Accessed: 26 February 2016).

Hakkarainen, P. (2009) 'Why should university students produce videos about their subject matter?' In: Proceedings of The IADIS International Conference On Cognition \& Exploratory Learning In Digital Age, pp. 491-493. Abingdon: Taylor and Francis.

Mayer, R. and Gallini, J. (1990) 'When is an illustration worth ten thousand words?' Journal of Educational Psychology, 82(6), 715-726.

Roberts, S. and Holton, V. (2015) Social Mobility: Experience, Expertise and Innovation in UK Business. London: ELBA.

Robertson, M. and Collins, A. (2003) 'The video role model as an enterprise teaching aid.' Education + Training, 45(6), 331-340.

Shaw, S. and Fairhurst, D. (2008) 'Engaging a new generation of graduates.' Education + Training, 50(5) 366-378.

Shepard, R. and Cooper, L. (1982) Mental images and their transformations. Cambridge, MA: MIT Press/Bradford Books.

Stoneham, R., Nyaga, C. and Sadykova, E. (2016) 'Panopto as an effective assessment tool.' In: SHIFT 2016: Annual Festival of Learning and Teaching, University of Greenwich. 8 January 2016 Available at:

https://showtime.gre.ac.uk/index.php/edu/shift2016/paper/viewPaper/852 (Accessed: 3 February 2016).

University of Greenwich (2014) Strategic Implementation Plan for Greenwich Connect Available at: http://blogs.gre.ac.uk/greenwichconnect/files/2014/08/Greenwich-ConnectStrategic-Implementation-Plan-Final.pdf (Accessed: 27 February 2016). 
Wilmot, P., Bramhall, M. and Radley, K. (2012) Using digital video reporting to inspire and engage students. Available at:

http://www.raeng.org.uk/education/hestem/heip/pdf/Using digital video reporting.pdf (Accessed: 30 October 2015). 